\title{
Experimental Study on Mechanical Properties of Novel FRP Bars with Hoop Winding Layer
}

\author{
Yue Liu $\mathbb{D}^{1,2}$ Hong-Tao Zhang ${ }^{1},{ }^{1}$ Hong-Hao Zhao, ${ }^{1}$ Lin Lu, ${ }^{3}$ Ming-Yang Han, ${ }^{3}$ \\ Jiao-Cai Wang, ${ }^{3}$ and Shuai Guan ${ }^{1}$ \\ ${ }^{1}$ The Key Laboratory of Urban Security and Disaster Engineering of Ministry of Education, Beijing University of Technology, \\ 100 Pingleyuan, Beijing, China \\ ${ }^{2}$ Central Research Institute of Building and Construction Co.,Ltd., MCC, 33 Xitucheng Road, Beijing, China \\ ${ }^{3}$ Anhui Province Highway \& Port Engineering Co.,Ltd., 459 Huangshan Road, Hefei, China
}

Correspondence should be addressed to Hong-Tao Zhang; htzhang@emails.bjut.edu.cn

Received 11 June 2021; Accepted 14 July 2021; Published 4 August 2021

Academic Editor: Haohui Xin

Copyright (C) 2021 Yue Liu et al. This is an open access article distributed under the Creative Commons Attribution License, which permits unrestricted use, distribution, and reproduction in any medium, provided the original work is properly cited.

\begin{abstract}
Due to the fact that steel reinforcement is vulnerable to corrosion, FRP bars with light weight, high strength, and excellent durability have become a good substitute for ordinary steel bars. FRP bars have high tensile strength, but their compressive strength is relatively low and often neglected, so the application of FRP bars in compression members has been restricted. This paper proposes a new pultrusion-winding-pultrusion method to improve the compressive ability of FRP bars. A hoop FRP layer is winded on the outer surface of the pultruded FRP core, and a longitudinal pultruded layer and ribs are also added on the outermost surface. In this paper, mechanical properties of this novel FRP bar with hoop winding layer are investigated. First, monotonic tensile and compressive tests on traditional and novel GFRP bars were conducted. Then, cyclic tension-compression loading tests were also carried out on the two types of GFRP bars. Test results showed that the compressive ultimate bearing capacities of GFRP bars with winding layers were $10 \sim 20 \mathrm{kN}$ greater than those of the traditional GFRP bars, and the compressive ductility of the novel GFRP bars was also improved. Furthermore, the tensile stress-strain behaviors of both GFRP bars were linear-elastic and the added winding layer did not greatly influence the tensile properties of the GFRP bars. Moreover, for the cyclic loading test, the compressive ultimate load of GFRP bars was $80 \% \sim 90 \%$ of that under monotonic compressive test, and the tensile ultimate load was $45 \% \sim 65 \%$ of that under monotonic tensile test. Compared with the GFRP bar without winding layer, the overall stiffness of the novel GFRP bar was greater than that of the traditional one and the ultimate load of the novel GFRP bar was also greater. In addition, seeing that the residual displacement of the novel GFRP bar was greater than that of the traditional GFRP bar, winding hoop fibers on the outer surface of the core is a useful way to improve the energy dissipation capacity of the GFRP bar.
\end{abstract}

\section{Introduction}

Reinforced concrete structure is one of the most widely used structures at present [1]. The steel reinforcements and concrete work together through the bonding force to give full play to their respective advantages, so the reinforced concrete structures can have good load-bearing capacity. Furthermore, their project cost is relatively low. However, steel reinforcements are susceptible to harsh environments, such as marine, humid, and deicing salt environments, which may cause the severe corrosion of steel bars and greatly reduce the service life of reinforced concrete structure, and even result in the structural failure. The corrosion of steel reinforcements has caused huge infrastructure maintenance cost. According to statistics, nearly $1 / 11$ of reinforced concrete bridges in USA are in various degrees of structural damage states due to reinforcement corrosion, which cost the government more than $\$ 20$ billion per year on 
maintenance [2]. In China, more than $¥ 200$ billion are spent to deal with the structural damage caused by corrosion every year, which accounts for about 3\% of Chinese GDP, and the cost of steel reinforcement corrosion accounts for a large proportion [3].

Fiber-reinforced polymer (FRP) is a high-performance composite material with advantages such as light weight [4], high strength [5], and excellent corrosion resistance [6]. Common FRPs can be mainly divided into four types according to the different types of fibers used, namely, glass fiber-reinforced polymer (GFRP), carbon fiber-reinforced polymer (CFRP), basalt fiber-reinforced polymer (BFRP), and aramid fiber-reinforced polymer (AFRP) [7]. Replacing ordinary steel bars with FRP bars in reinforced concrete structures is able to not only maintain the advantages of traditional reinforced concrete structure but also fundamentally solve the problem of steel corrosion and hence significantly improve the durability of structures. In addition, with FRP reinforcements, the self-weight of the structures can be also reduced, which is beneficial for fabricated structures.

The research of FRP bars' application to reinforced concrete structures began in USA in the 1960s. At that time, due to the widespread use of deicing salts, many serious corrosion problems occurred to the steel bars in concrete highway bridges [8]. Thereafter, studies on FRP-reinforced concrete structures were carried out in Japan, Canada, China, and many other countries [9-11]. Up to present, the related studies of FRP-reinforced concrete structures mainly includes the mechanical properties and durability of FRP bars [12-15], the bonding properties between FRP bars and concrete [16-18], the failure mode and design theory of FRP reinforced concrete beams [19-22], columns [23-27], joints [28-31], and fire resistance [32, 33].

Deep research promoted the application of FRP bars, especially the relatively cheap GFRP bars in engineering structures, and many countries have published their codes and standards of FRP reinforced concrete structures [34-36]. FRP bars have been widely used in engineering structures for their excellent tensile properties $[37,38]$; however, they have some mechanical problems, including the following: (1) their elastic modulus is lower than that of steel bars, which leads to smaller stiffness, larger deformation, and more serious cracking of concrete structures under load; (2) the stress-strain curve of FRP bars is linear, there is no obvious yield point, and the ductility of FRP bars is poor; (3) the fire resistance of FRP bars is poor; and (4) the mechanical properties of FRP bars are different under compressive and tensile loads, and the compressive strength of FRP bars is much lower than the tensile strength. The compressive properties of FRP bars were studied by Maranan et al. [25], Khan et al. [39], Khorramian and Sadeghian [40], and other researchers [41-45]; their studies indicate that the compressive strength of FRP bars is only approximate $50 \% \sim 60 \%$ of the tensile strength. For the contribution of FRP bars in the compressive load-bearing capacity of reinforced concrete structural members, many codes choose to neglect it (e.g., ACI 440. 1R. 2015 [35], CAN/CSA S806-12 2012 [46], and Fib Bulletin 402007 [34]), because the compressive strength and ductility of FRP bars are regarded as too small.
So far, few scholars have explored the mechanical properties of FRP bars under cyclic loading. Kobayashi and Fujisaki [47] tested the ultimate strength of CFRP, GFRP, and AFRP bars under monotonic compressive and tensile loads and then studied the mechanical properties of the three types of bars under progressively increasing cyclic tension and compression load, respectively. It is concluded that under cyclic loading the compressive strengths of AFRP bars and GFRP bars are 20\% 50\% of that under monotonic loading, whereas the cyclic loading has almost no effect on the mechanical properties of CFRP bars. Wu et al. [48] proposed a novel steel-FRP composite bar (SFCB) and applied monotonic and cyclic tensiletensile loads on it. It is found that the stress-strain curve of SFCB under monotonic loading presents bilinear characteristics, and the specimen has stable secondary stiffness after yielding. Under cyclic loading, SFCB has small residual deformation and good recoverable performance, and the cyclic tensile load does not significantly weaken its strength and stiffness.

In this paper, a novel method is proposed to improve the compressive load-bearing capacity and ductility of FRP bars, namely, winding hoop impregnated fibers around the outer surface of pultruded FRP bars. Firstly, the manufacture process of the FRP bars with winding layer was introduced. Then, the tensile and compressive properties were studied through monotonic tensile and compressive tests, respectively. Finally, the mechanical properties of novel FRP bars under cyclic tension and compression loading were investigated and compared with the traditional FRP bars.

\section{Manufacturing of FRP Bars with Hoop Winding Layer}

The production process of the novel FRP bar can be divided into four steps, as depicted in Figure 1. First, the core of the FRP bar is manufactured by the pultrusion process. The direction of the fibers in the core is longitudinal, which is consistent with the traction direction of the pull rollers. In the process of the pultrusion, the pulling speed is set to $1.2 \mathrm{~m} / \mathrm{min}$. The pre-die former is divided into 8 drying tunnels, and the temperature is reduced from $220^{\circ} \mathrm{C}$ to $160^{\circ} \mathrm{C}$ gradually, so the resin can be set and hardened sufficiently. After the core is produced, the fibers are impregnated and winded on the outer surface of the core. This process is also called the filament winding. The speed of the rotating device is 1.2-1.6 times of the pultrusion speed. By controlling the winding time of the rotating device, the winding layer with certain thickness can be achieved. After the winding layer is manufactured, a thin layer with longitudinal fibers is added on the outermost surface through the pultrusion; this process can ensure a good surface condition of the FRP bar and protect the hoop winding layer.

For the traditional FRP bar, after the completion of the pultrusion, the ribs are winded on the surface of the core in the circumferential direction. However, for the novel FRP bar, the ribs are added on the outermost longitudinal pultruded layer by the filament winding (see Figure 1). 


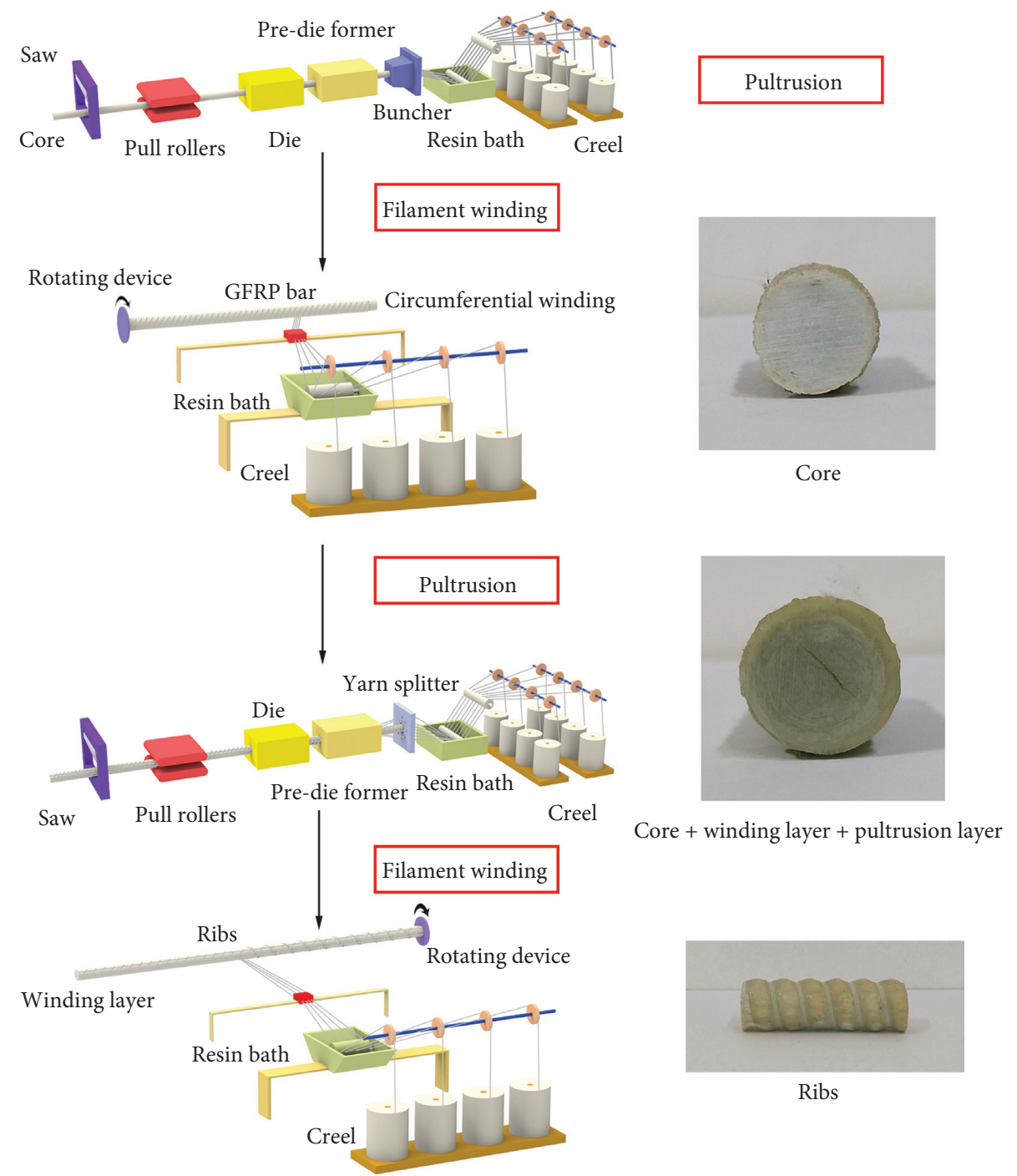

Figure 1: Manufacturing process of the novel GFRP bar.

\section{Compressive and Tensile Properties}

3.1. Materials. The glass fiber was produced by Taian Glass Fiber Co., Ltd., and the resin was produced by Jiangsu Jinlong New Material Co., Ltd. The core, winding layer, and ribs were all manufactured by E-glass fibers with a monofilament diameter of 24 microns. Moreover, the E-glass fibers in the core were $4800 \mathrm{TEX}$, and those in the winding layers and ribs were $1200 \mathrm{TEX}$. The resins used in the core, winding layer, and ribs were all unsaturated polymer resin. The manufacturer provided the mechanical properties of the E-glass fiber and resin, which are listed in Table 1. In order to ensure the consistency of the experimental data, all the GFRP bars were produced in the same batch. The mass fractions of the fibers and resin are $80 \%$ and $20 \%$, respectively.

3.2. Test Matrix. The specimens of traditional and novel GFRP bars were prepared. The traditional GFRP bar with a diameter of $16 \mathrm{~mm}$ was used as the control group in the experiment. The novel GFRP bar's core diameter was $16 \mathrm{~mm}$ and total diameter was $21 \mathrm{~mm}$, because a hoop winding layer with the thickness of $1.5 \mathrm{~mm}$ and a $1 \mathrm{~mm}$ pultrusion layer were added outside of the core. Table 2 shows the details and specifications of compressive and tensile specimens. According to GB/T 1448-2005 "Fiber-reinforced plastics composites-determination of compressive properties" [49] and GB/T 30022-2013 "Test method for basic mechanical properties of fiber reinforced polymer bar" [50], the compressive and tensile tests were conducted. The control GFRP bar was termed as $\mathrm{C}$ specimen, and the novel GFRP bar was termed as $\mathrm{W}$ specimen.

Two kinds of specimens with different heights of $40 \mathrm{~mm}$ and $60 \mathrm{~mm}$ were prepared for the compressive test, and the total length of the specimen under tensile test was $1000 \mathrm{~mm}$. There were five specimens for each case. In the compressive test, taking specimen C-H40-1 as an example, where "C" stands for GFRP bars without winding layer, "H40" means that the height of the specimen is $40 \mathrm{~mm}$, and " 1 " stands for the first specimen in the testing group; other specimens were 
TABLE 1: Mechanical properties of glass fiber and resin.

\begin{tabular}{lcccccc}
\hline Material & $\begin{array}{c}\text { Density } \\
\left(\mathrm{g} / \mathrm{cm}^{3}\right)\end{array}$ & Poisson's ratio & $\begin{array}{c}\text { Elastic } \\
\text { modulus }(\mathrm{GPa})\end{array}$ & $\begin{array}{c}\text { Shear } \\
\text { modulus }(\mathrm{GPa})\end{array}$ & $\begin{array}{c}\text { Tensile } \\
\text { strength }(\mathrm{MPa})\end{array}$ & Compressive strength (MPa) \\
\hline E-glass fiber & 2.49 & 0.25 & 78 & 32 & 2050 & 1130 \\
Unsaturated polymer resin & 1.3 & 0.3 & 3.2 & 1.3 & 87 & 108 \\
\hline
\end{tabular}

TABLE 2: Details of test specimens.

\begin{tabular}{lccccc}
\hline $\begin{array}{l}\text { Group } \\
\text { notation }\end{array}$ & $\begin{array}{c}\text { Number of winding } \\
\text { layers }\end{array}$ & $\begin{array}{c}\text { Diameter } \\
(\mathrm{mm})\end{array}$ & $\begin{array}{c}\text { Cross-sectional area } \\
\left(\mathrm{mm}^{2}\right)\end{array}$ & $\begin{array}{c}\text { Length } \\
(\mathrm{mm})\end{array}$ & Specimen ID \\
\hline C-H40 & 0 & 16 & 200.96 & 40 & C-H40-1, C-H40-2, C-H40-3, C-H40-4, \\
C-H40-5
\end{tabular}

labeled in the same way. In the tensile test, taking specimen T-C-1 as an example, which "T" stands for tensile test, "C" stands for GFRP bars without hoop winding layer, and " 1 " stands for the first specimen in the testing group. The photos of GFRP bars are shown in Figure 2.

3.3. Test Setup. For the compressive test, the H40 and H60 specimens were loaded by a $1000 \mathrm{kN}$ MTS universal testing machine. The loading system was established according to the Chinese code GB/T 1448-2005 "Fiiber-reinforced plastics composites determination of compressive properties" [49], as shown in Figure 3. The displacement loading method was adopted, and the loading rate was set to $2 \mathrm{~mm} / \mathrm{min}$. The actual strain during loading was recorded by axial strain gauge pasted on the GFRP bar surface in the middle. The bottom of the universal testing machine was a spherical hinge, which can automatically level the specimen when the compressive load was biased. At the end of the test, all the data were collected and recorded by DH3816N static data logger.

For the tensile test, it is noted that the transversely shear strength of GFRP bar is relatively low, in order to prevent the specimen from early failure at the loading end, steel pipes with internal threads were installed at both ends of GFRP bars according to the Chinese code GB/T 30022-2013 "Test method for basic mechanical properties of fiber reinforced polymer bar" [50], and the steel pipes and GFRP bars were bonded by high-strength grouting material. As shown in Figure 4, the length of anchorage part and free part of tensile specimens were $350 \mathrm{~mm}$ and $300 \mathrm{~mm}$, respectively. The loading rate of the test was $2 \mathrm{~mm} / \mathrm{min}$, and the actual strain of the specimen during the loading was measured by the strain gauge pasted on the surface of the middle of the specimen as shown in Figure 5.

\subsection{Compressive Test Results and Discussion}

3.4.1. Ultimate Load and Compressive Strength. Figure 6 shows the failure modes of GFRP bars; it can be found that the splitting failure occurred at both the $\mathrm{C}$ and $\mathrm{W}$ specimens.

The ultimate loads borne by $\mathrm{C}$ specimens and $\mathrm{W}$ specimens are listed in Tables 3 and 4, respectively, and are compared in Figure 7.

It can be seen that the ultimate load of C-H60 specimens was slightly less than that of $\mathrm{C}-\mathrm{H} 40$ specimens, and the ultimate load of $\mathrm{W}-\mathrm{H} 60$ specimens was also less than that of W-H40 specimens. The ultimate compressive load of the same type of GFRP bars decreased with the increase of height due to the influence of slenderness.

In addition, when the height of the GFRP bar is same, the ultimate load of the GFRP bars with winding layer (W) increased by $10 \sim 20 \mathrm{kN}$ compared with that of the GFRP bar without winding layer (C). The ultimate load of H40 GFRP bars increased by $10.9 \%$ with an additional winding layer. Similarly, the ultimate load of H60 GFRP bars increased by $19.5 \%$ with the winding layer. The trend in Figure 7 indicates that the winding layer can help increasing the GFRP bar's ultimate compressive load.

Compressive strengths of $\mathrm{C}$ specimens and $\mathrm{W}$ specimens are presented in Tables 5 and 6 , respectively. The compressive strength was obtained by dividing the compressive load $\left(P_{u}\right)$ with the nominal cross-sectional area $(A)$ as specified by the Chinese code GB/T 1448-2005 "Fiberreinforced plastics composites-determination of compressive properties" [49]. The nominal diameter of C specimens and $\mathrm{W}$ specimens is $16 \mathrm{~mm}$. Therefore, the nominal cross-sectional area $A$ is equal to $200.96 \mathrm{~mm}^{2}$. With one winding layer, the compressive strengths of the $\mathrm{H} 40$ and H60 specimens were increased by $10.9 \%$ and $19.5 \%$, respectively. 


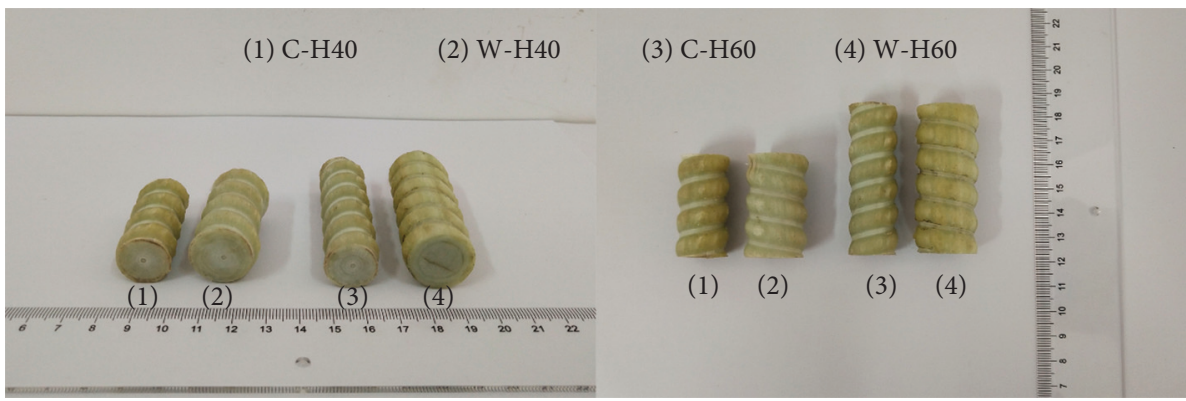

Figure 2: C and W specimens.

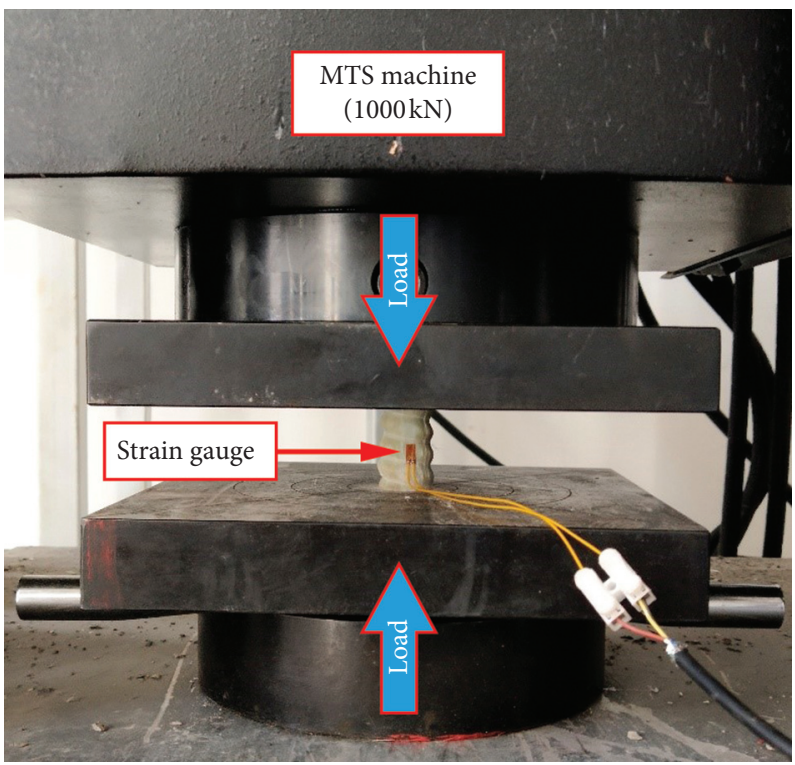

Figure 3: Compressive test setup.

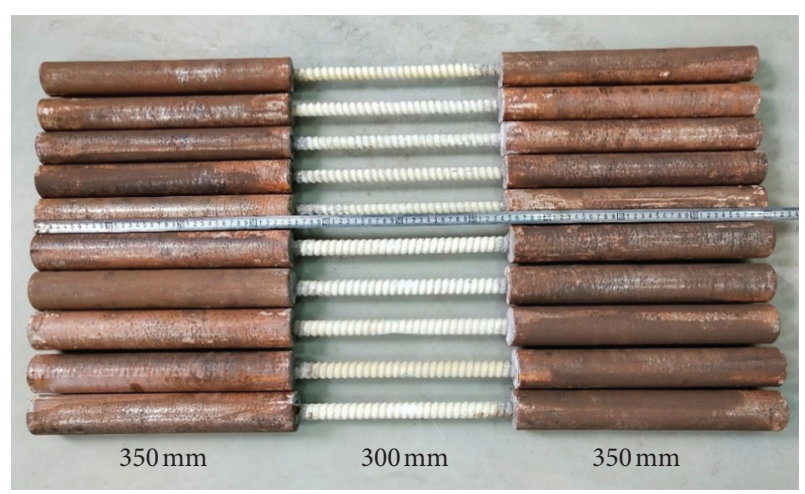

Figure 4: Tensile specimens of GFRP bars.

Figure 8 shows the change trend of the compressive strength of GFRP bars; it can be seen that the winding layer has a positive effect on increasing the compressive strength for both heights of GFRP bars.

Figures 9 and 10 show the stress-strain curves of $\mathrm{C}$ specimens and $\mathrm{W}$ specimens, respectively. It can be seen from Figures 9(a) and 9(b) that the stress-strain curves of $\mathrm{C}$ specimens changed linearly during the loading process, but Figures 10(a) and 10(b) indicate that the stress-strain curves of the $\mathrm{W}$ specimens appeared to be nonlinear to a certain extent; namely, many specimens have an approximate horizontal segment before failure. This also indicates that the ductility of the GFRP bars has been improved by winding hoop fibers on the surface of the core.

The compressive modulus of elasticity was also calculated apart from the ultimate load and compressive strength. According to the Chinese code GB/T 1448-2005 "Fiberreinforced plastics composites-determination of compressive properties" [49], the compressive modulus of elasticity was calculated by

$$
E_{c}=\frac{\sigma_{2}-\sigma_{1}}{\varepsilon_{2}-\varepsilon_{1}}
$$

where $\varepsilon_{1}$ is the strain at $0.05 \mu \varepsilon$ during the loading process, $\varepsilon_{2}$ is the strain at $0.25 \mu \varepsilon$ during the loading process, and $\sigma_{1}$ and $\sigma_{2}$ are the stresses corresponding to $\varepsilon_{1}$ and $\varepsilon_{2}$, respectively.

The calculated compressive moduli of $\mathrm{C}$ specimens and W specimens are listed in Tables 7 and 8 . As can be seen, the elastic modulus of the $\mathrm{W}$ specimen was significantly greater than that of the $\mathrm{C}$ specimen. 


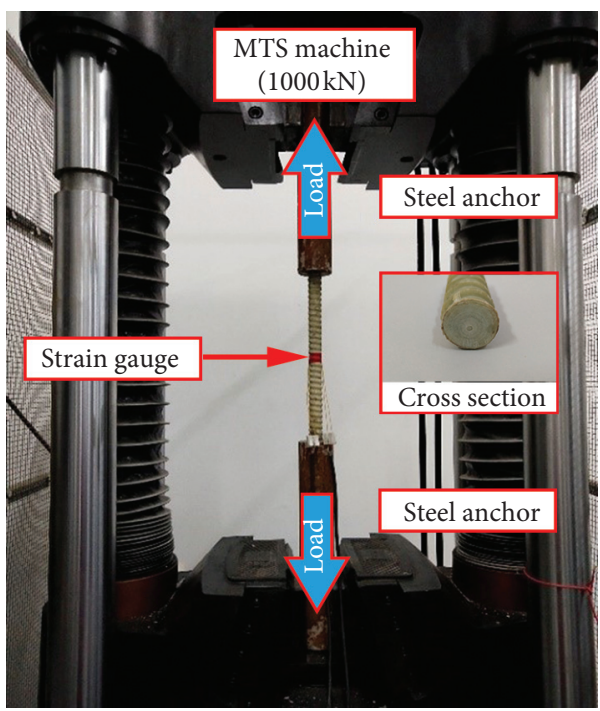

(a)

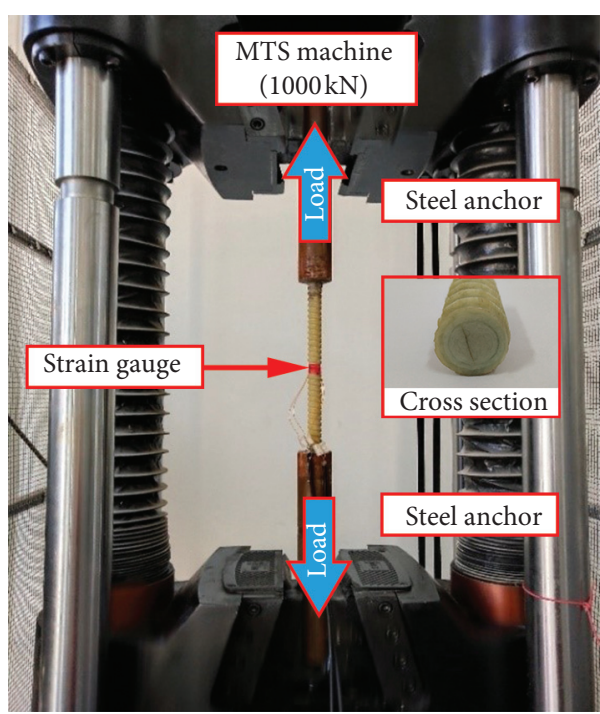

(b)

Figure 5: Tensile test setup. (a) T-C GFRP bar. (b) T-W GFRP bar.

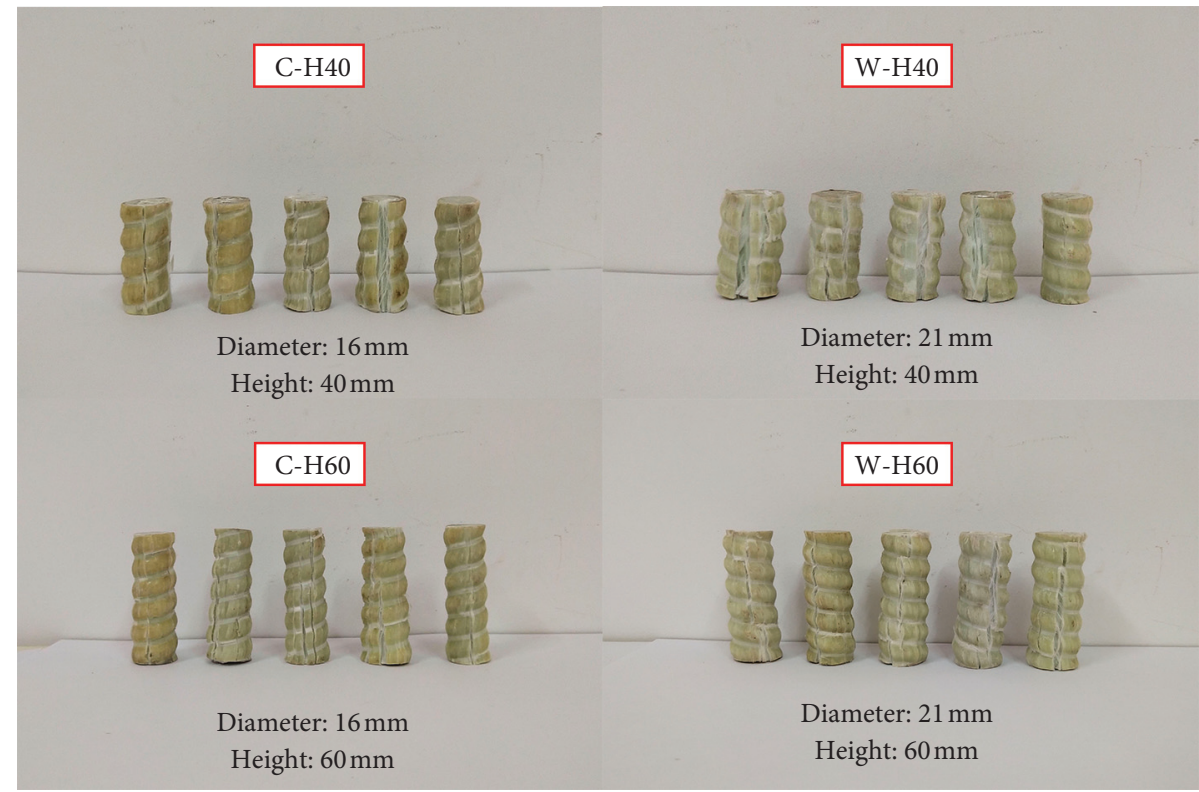

FIgUre 6: Compressive failure modes of GFRP bars.

TABle 3: Ultimate load of $\mathrm{C}$ specimens.

\begin{tabular}{|c|c|c|c|c|c|}
\hline Specimen & Ultimate load $(\mathrm{kN})$ & Average $(\mathrm{kN})$ & Improvement (\%) & SD & $\mathrm{CV}$ \\
\hline C-H40-1 & 101.266 & & & & \\
\hline C-H40-2 & 78.892 & & & & \\
\hline C-H40-3 & 85.764 & 92.941 & - & 9.201 & 0.099 \\
\hline C-H40-4 & 102.697 & & & & \\
\hline C-H40-5 & 96.089 & & & & \\
\hline W-H40-1 & 100.894 & & & & \\
\hline W-H40-2 & 103.255 & & & & \\
\hline W-H40-3 & 107.862 & 103.113 & 10.9 & 2.495 & 0.024 \\
\hline W-H40-4 & 101.613 & & & & \\
\hline W-H40-5 & 101.941 & & & & \\
\hline
\end{tabular}


TABLE 4: Ultimate load of W specimens.

\begin{tabular}{|c|c|c|c|c|c|}
\hline Specimen & Ultimate load $(\mathrm{kN})$ & Average $(\mathrm{kN})$ & Improvement (\%) & SD & $\mathrm{CV}$ \\
\hline C-H60-1 & 86.366 & & & & \\
\hline C-H60-2 & 70.429 & & & & \\
\hline C-H60-3 & 81.769 & 84.820 & - & 8.760 & 0.103 \\
\hline C-H60-4 & 97.159 & & & & \\
\hline C-H60-5 & 88.378 & & & & \\
\hline W-H60-1 & 108.659 & & & & \\
\hline W-H60-2 & 105.151 & & & & \\
\hline W-H60-3 & 95.087 & 101.327 & 19.5 & 7.780 & 0.077 \\
\hline W-H60-4 & 108.441 & & & & \\
\hline W-H60-5 & 89.297 & & & & \\
\hline
\end{tabular}

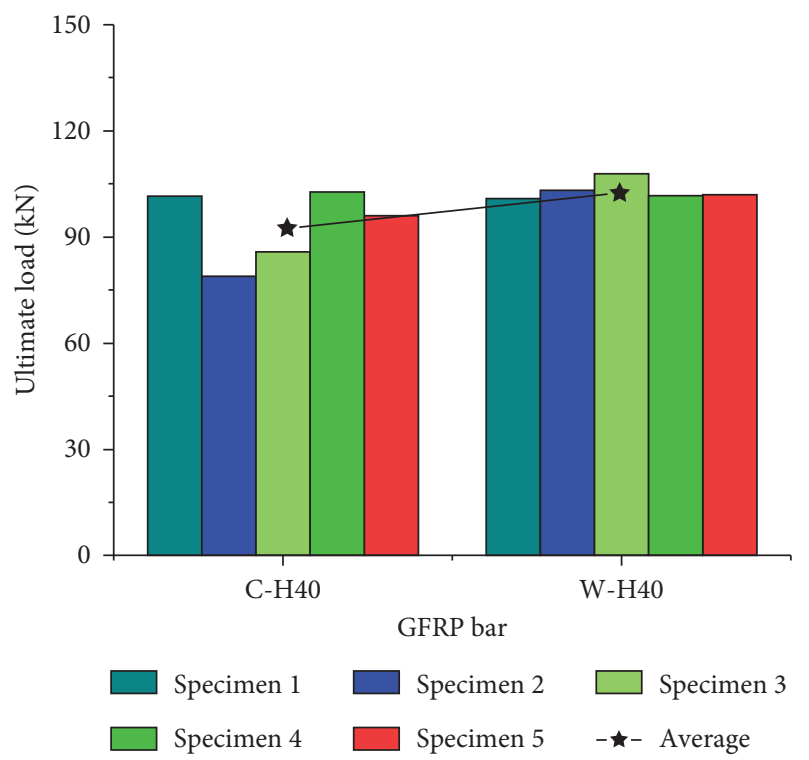

(a)

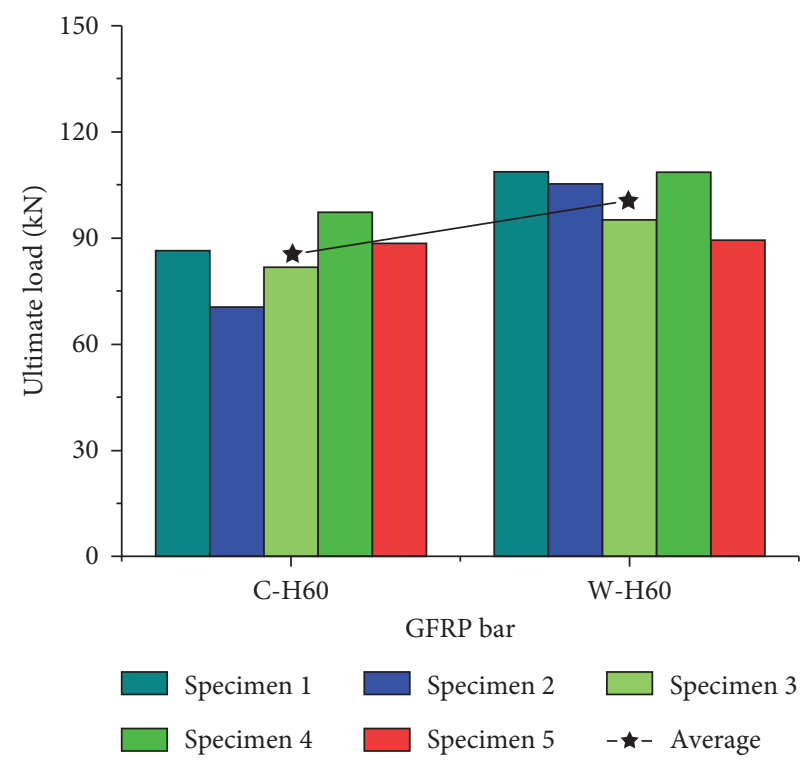

(b)

FIgURE 7: Ultimate load comparison of $\mathrm{C}$ specimens and W specimens with different heights. (a) H40 specimens. (b) H60 specimens.

TABLe 5: Compressive strength of $\mathrm{C}$ specimens.

\begin{tabular}{|c|c|c|c|c|c|}
\hline Specimen & Compressive strength (MPa) & Average $(\mathrm{MPa})$ & Improvement (\%) & SD & $\mathrm{CV}$ \\
\hline C-H40-1 & 503.911 & & & & \\
\hline C-H40-2 & 392.576 & & & & \\
\hline C-H40-3 & 426.771 & 462.487 & - & 45.784 & 0.099 \\
\hline C-H40-4 & 511.032 & & & & \\
\hline $\mathrm{C}-\mathrm{H} 40-5$ & 478.150 & & & & \\
\hline W-H40-1 & 502.060 & & & & \\
\hline $\mathrm{W}-\mathrm{H} 40-2$ & 513.809 & & & & \\
\hline W-H40-3 & 536.734 & 513.102 & 10.9 & 12.414 & 0.024 \\
\hline W-H40-4 & 505.638 & & & & \\
\hline W-H40-5 & 507.270 & & & & \\
\hline
\end{tabular}

3.5. Tensile Test Results and Discussion. In the initial stage of loading, the sound of fiber breakage could be heard sparsely. As the load continued to increase, the sound of internal fibers being pulled to rupture became louder. When the load approached the ultimate load, a loud noise could be heard from the GFRP bar, and the specimen burst like a lantern.
Figures 11(a) and 11(b) show the failure mode of T-C specimen and $\mathrm{T}-\mathrm{W}$ specimen, respectively.

The ultimate tensile load and tensile stress of T-C specimens and T-W specimens are presented in Tables 9 and 10. The difference of average ultimate tensile load between the two types of GFRP bars was not obvious, which was due 
TABLE 6: Compressive strength of $\mathrm{W}$ specimens.

\begin{tabular}{|c|c|c|c|c|c|}
\hline Specimen & Compressive strength (MPa) & Average $(\mathrm{MPa})$ & Improvement (\%) & $\mathrm{SD}$ & $\mathrm{CV}$ \\
\hline C-H60-1 & 429.767 & & & & \\
\hline C-H60-2 & 350.465 & & & & \\
\hline C-H60-3 & 406.891 & 422.074 & - & 43.591 & 0.103 \\
\hline $\mathrm{C}-\mathrm{H} 60-4$ & 483.473 & & & & \\
\hline C-H60-5 & 439.777 & & & & \\
\hline W-H60-1 & 540.700 & & & & \\
\hline W-H60-2 & 523.243 & & & & \\
\hline W-H60-3 & 473.164 & 504.215 & 19.5 & 38.715 & 0.077 \\
\hline W-H60-4 & 539.615 & & & & \\
\hline W-H60-5 & 444.352 & & & & \\
\hline
\end{tabular}

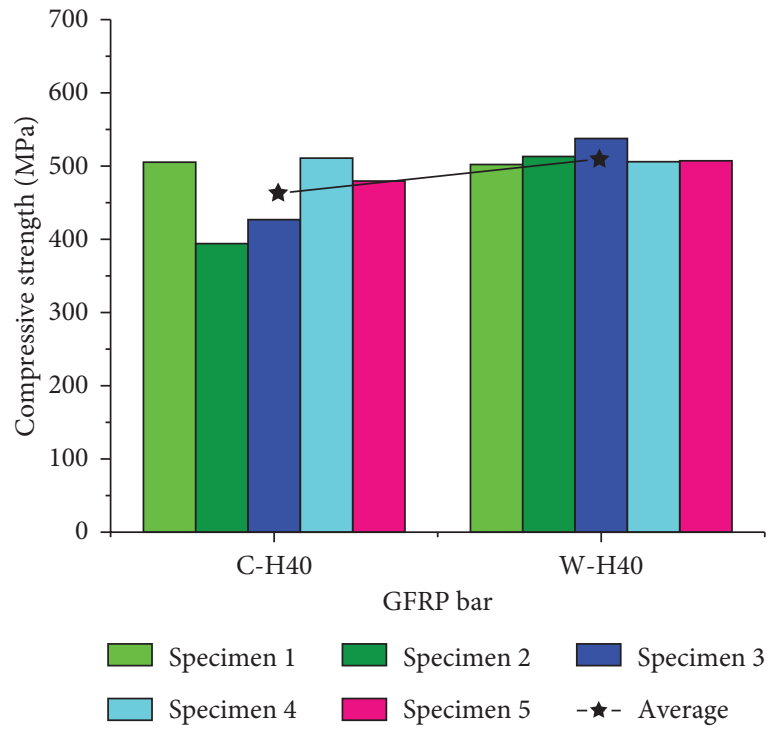

(a)

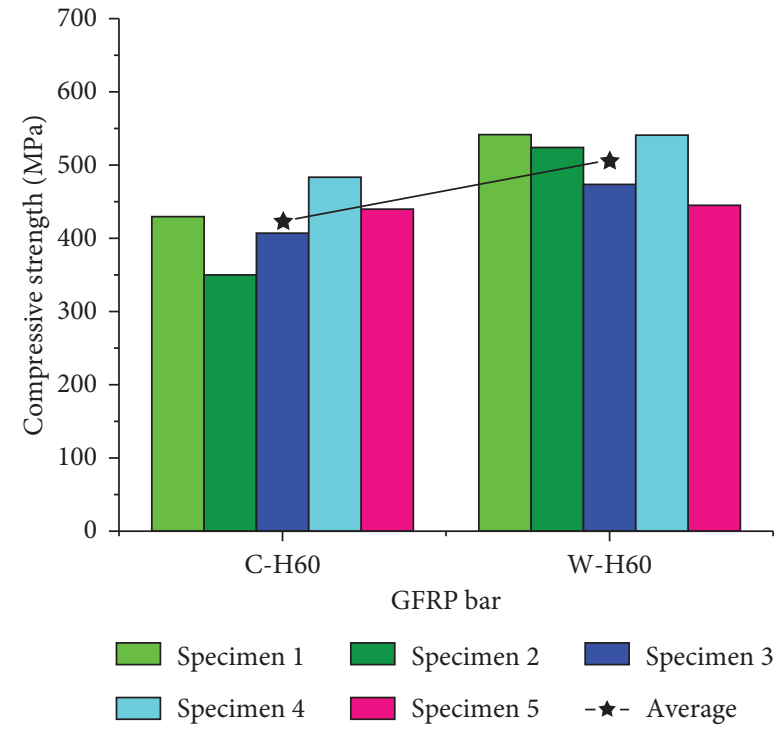

(b)

FIgURE 8: Compressive strength comparison of $\mathrm{C}$ specimens and $\mathrm{W}$ specimens with different heights. (a) H40 specimens. (b) H60 specimens.

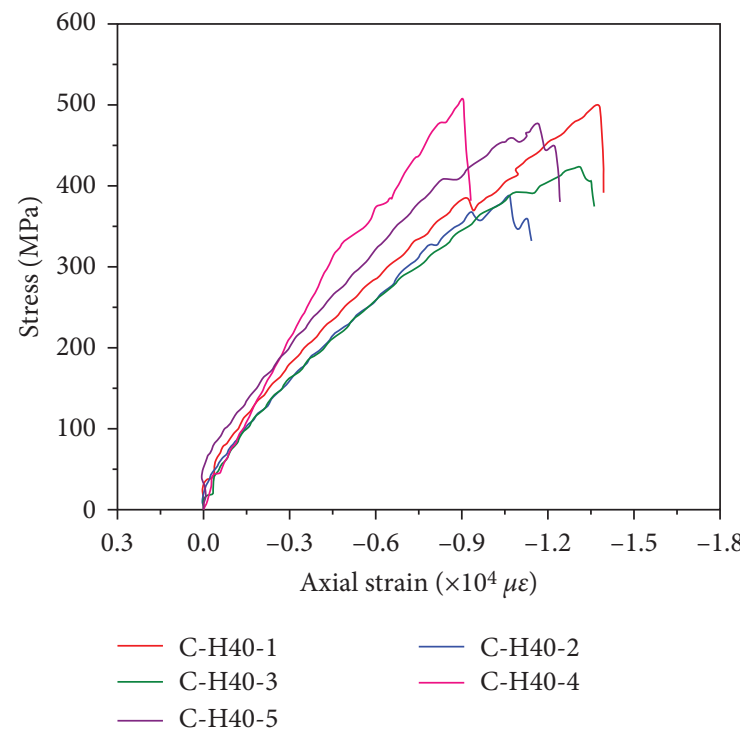

(a)

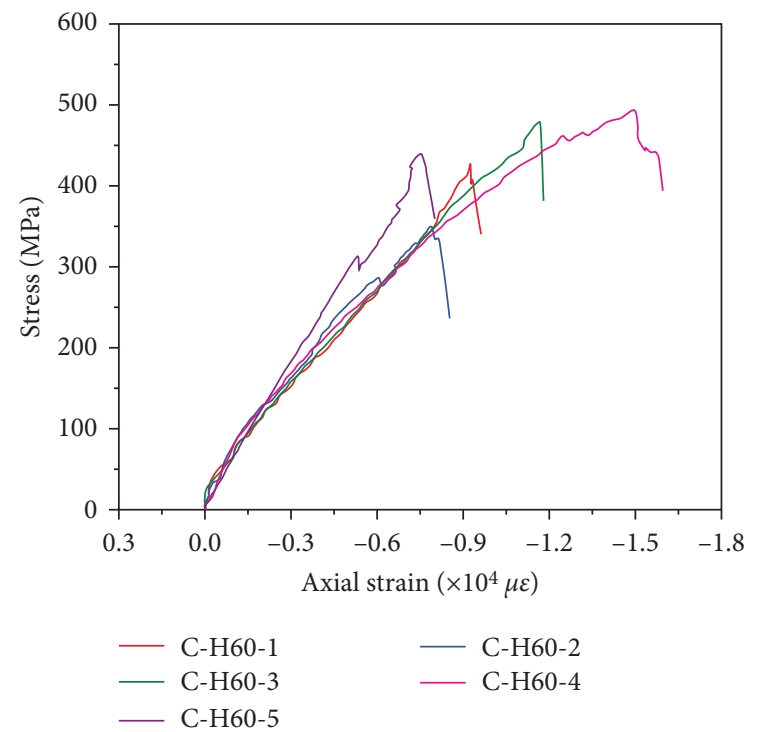

(b)

Figure 9: Stress-strain curves of C specimens under compressive load. (a) H40 specimens. (b) H60 specimens. 


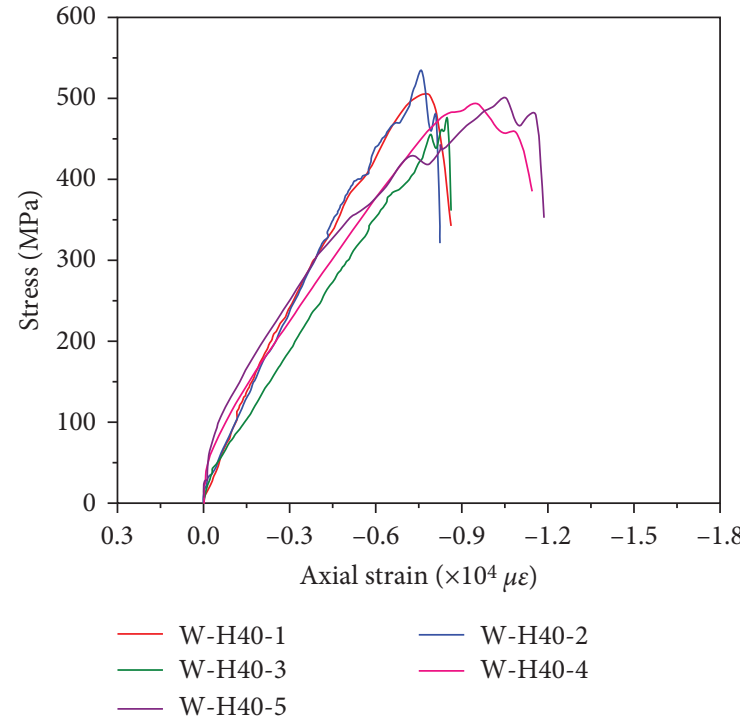

(a)

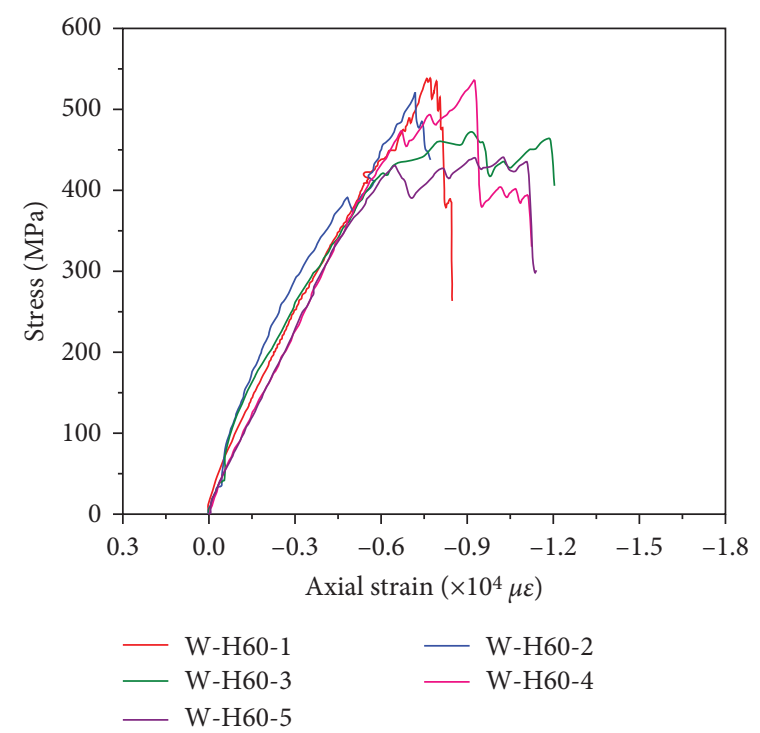

(b)

FIgURE 10: Stress-strain curves of W specimens under compressive load. (a) H40 specimens. (b) H60 specimens.

TABLE 7: Elastic modulus of H40 specimens in the compressive test.

\begin{tabular}{lccc}
\hline Specimens & E (GPa) & Average & SD \\
\hline C-H40-1 & 47.2 & & \\
C-H40-2 & 43.3 & 46.4 & 1.6 \\
C-H40-3 & 47.4 & & \\
C-H40-4 & 47.7 & & \\
C-H40-5 & 46.4 & 67.5 & 10.15 \\
\hline W-H40-1 & 77.7 & & 0.151 \\
W-H40-2 & 74.9 & & \\
W-H40-3 & 74.5 & & \\
W-H40-4 & 55.6 & & \\
W-H40-5 & 54.6 & & \\
\hline
\end{tabular}

TABLE 8: Elastic modulus of H60 specimens in the compressive test.

\begin{tabular}{lccc}
\hline Specimens & $E(\mathrm{GPa})$ & Average & SD \\
\hline C-H60-1 & 40.8 & & \\
C-H60-2 & 43.4 & 45.2 & 2.98 \\
C-H60-3 & 44.8 & & \\
C-H60-4 & 48.4 & & \\
C-H60-5 & 48.6 & & \\
\hline W-H60-1 & 71.9 & 73.0 & 2.066 \\
W-H60-2 & 76.0 & & 0.031 \\
W-H60-3 & 75.6 & & \\
W-H60-4 & 70.7 & & \\
W-H60-5 & 71.0 & & \\
\hline
\end{tabular}




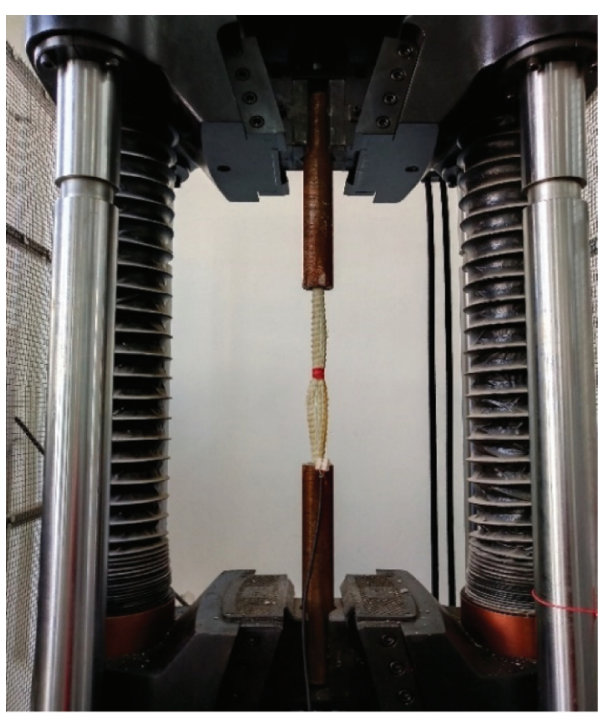

(a)

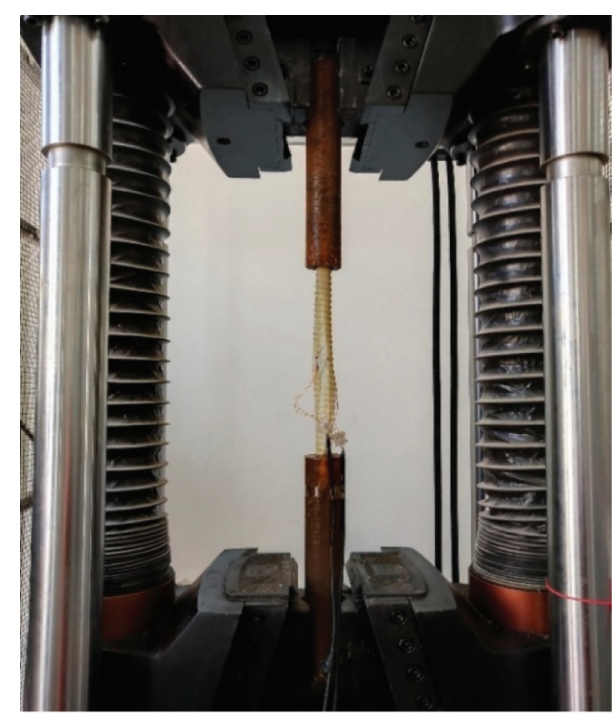

(b)

FIgURE 11: Tensile failure modes of GFRP bars. (a) T-C specimen. (b) T-W specimen.

TABLE 9: Ultimate load of GFRP bars in the tensile test.

\begin{tabular}{|c|c|c|c|c|}
\hline Specimen & Ultimate load $(\mathrm{kN})$ & Average $(\mathrm{kN})$ & $\mathrm{SD}$ & $\mathrm{CV}$ \\
\hline T-C-1 & 137.043 & & & \\
\hline T-C-2 & 123.276 & & & \\
\hline $\mathrm{T}-\mathrm{C}-3$ & 139.356 & 129.742 & 9.906 & 0.076 \\
\hline T-C-4 & 135.666 & & & \\
\hline T-C-5 & 113.370 & & & \\
\hline T-W-1 & 114.287 & & & \\
\hline T-W-2 & 133.039 & & & \\
\hline T-W-3 & 109.672 & 120.009 & 10.972 & 0.091 \\
\hline T-W-4 & 109.526 & & & \\
\hline T-W-5 & 133.524 & & & \\
\hline
\end{tabular}

to the fact that the axial fibers mainly carried the external load, and the winding fibers had little effect on the bearing capacity of the GFRP bar. Figures 12 and 13 present the ultimate load and tensile stress of the GFRP bars.

During the test, the outer surface of the GFRP bar first burst before the specimen failed, which caused the strain gauge failure in advance. Figures 14 and 15 show the measured stress-strain curve and load-displacement curve of $\mathrm{T}-\mathrm{C}$ specimens and T-W specimens, respectively.

Figure 16 shows the comparison of tensile elastic modulus. Taking the linearly elastic sections in Figure 14 for calculation, the values of each specimen's elastic modulus can be obtained. It can be found that the tensile modulus of elasticity of T-C specimens is smaller than the T-W specimens' tensile modulus of elasticity.

\section{Mechanical Properties under Cyclic Loading of Tension and Compression}

4.1. Test Setup. The premise of the test was to ensure that the GFRP bars did not buckle during the loading process. Considering the limitation of the fixture length of the universal testing machine; meanwhile, in order to prevent the slippage between the GFRP bar and the anchorage, the length of anchored section was set to be $200 \mathrm{~mm}$, and the free section of the GFRP bar was $100 \mathrm{~mm}$ long.

Table 11 shows the specifications of the specimens. A $300 \mathrm{kN}$ MTS low-cycle fatigue testing machine was used in the test. In order to ensure that both ends of the specimens were well fixed to the testing machine, the clamping load of the fixture on the anchorage was set to $15 \mathrm{MPa}$. The deformation of GFRP bar during the loading process was measured by LVDT. The test setup of cyclic loading is depicted in Figure 17.

As shown in Figure 18, a displacement-controlled loading process was adopted in the test. Furthermore, the loading rate was set to $0.05 \mathrm{~mm} / \mathrm{sec}$, and the loading frequency was $20 \mathrm{~Hz}$.

4.2. Test Results and Discussion. Figures 19(a) and 19(b) show the failure modes of TC-C specimens and TC-W specimens, respectively. All the failure modes of specimens were burst split, and cracks can be obviously observed in the free section of GFRP bars, which was the result of matrix crushing under the cyclic loading and the separation between fiber and resin. 
TABLE 10: Tensile stress of GFRP bars.

\begin{tabular}{lcccc}
\hline Specimen & Tensile stress $(\mathrm{MPa})$ & Average $(\mathrm{MPa})$ & SD & CV \\
\hline T-C-1 & 681.941 & & & \\
T-C-2 & 613.436 & 645.613 & 49.296 & \\
T-C-3 & 693.453 & & & \\
T-C-4 & 675.092 & & & \\
T-C-5 & 564.142 & & 54.597 & 0.091 \\
\hline T-W-1 & 568.707 & 597.181 & & \\
T-W-2 & 662.015 & & \\
T-W-3 & 545.739 & & \\
T-W-4 & 545.015 & 664.429 & & \\
T-W-5 & & & & \\
\hline
\end{tabular}

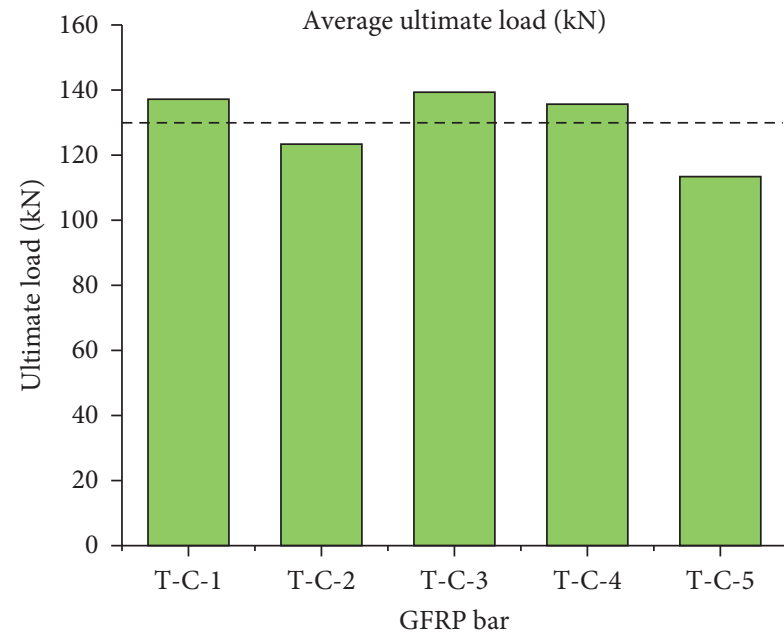

(a)

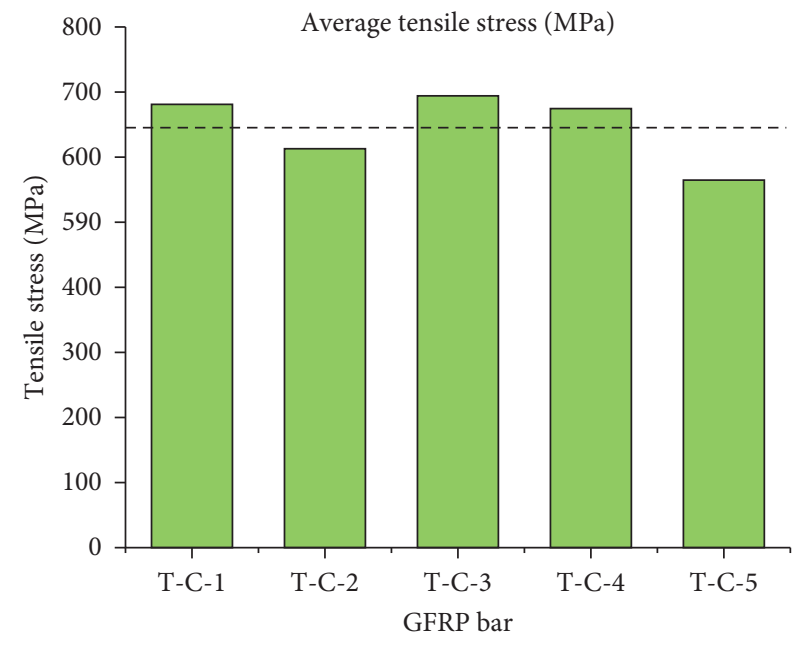

(b)

FIGURE 12: (a) Ultimate load comparison and (b) tensile stress comparison of T-C specimens.

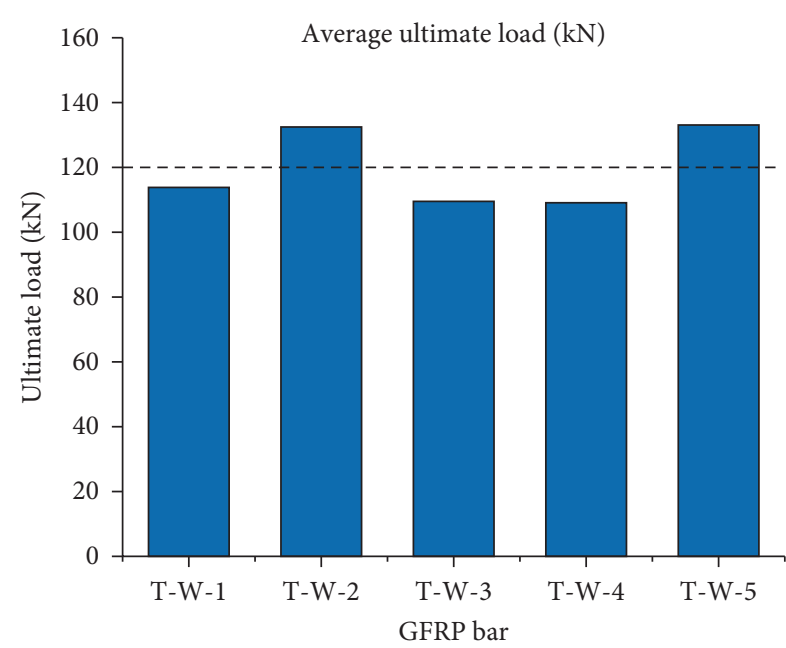

(a)

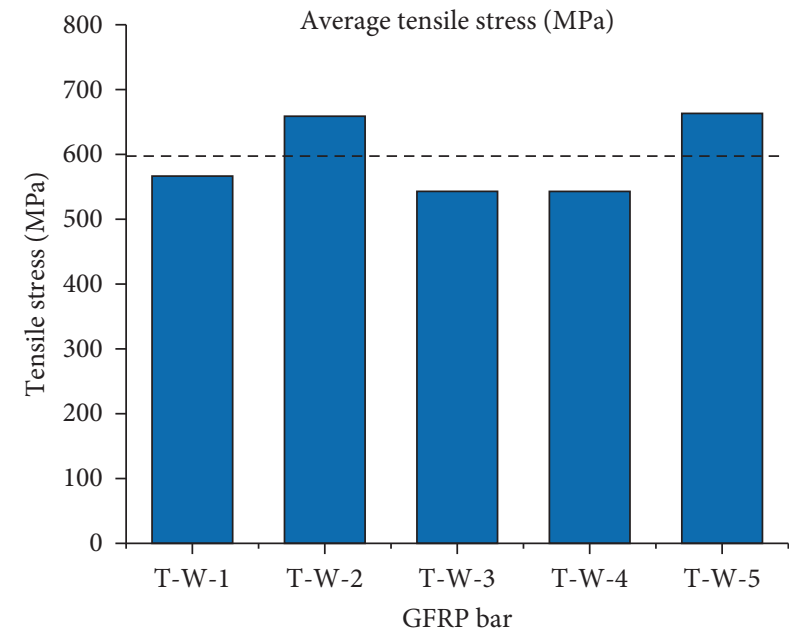

(b)

FIgURE 13: (a) Ultimate load comparison and (b) tensile stress comparison of T-W specimens. 


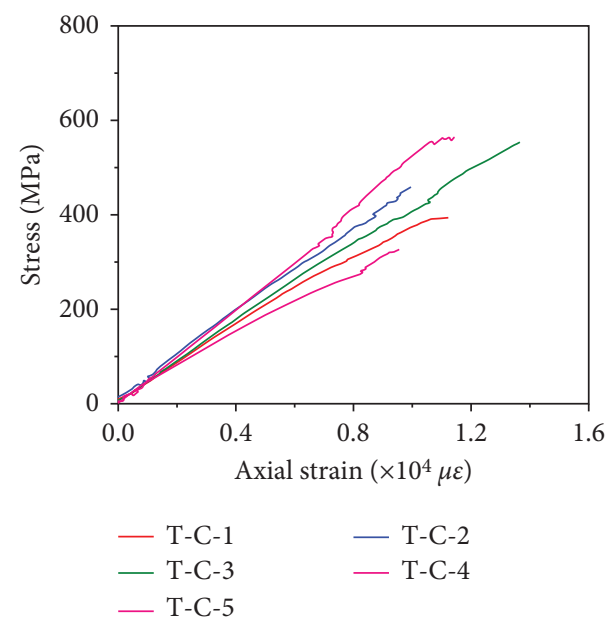

(a)

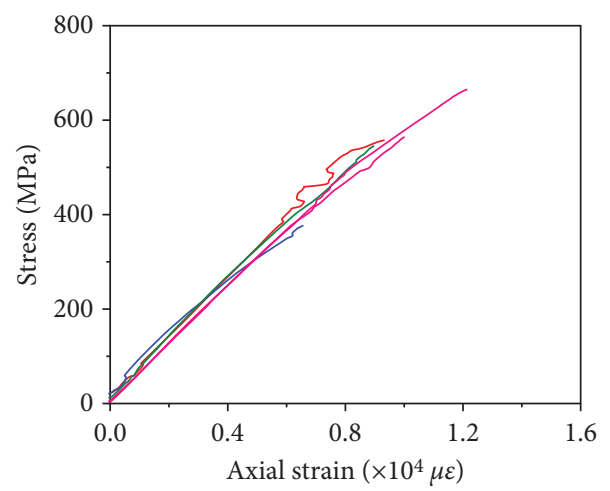

$$
\begin{array}{ll}
\text { T-W-1 } & \text { T-W-2 } \\
\text { T-W-3 } & \text { T-W-4 } \\
\text { T-W-5 } &
\end{array}
$$

(b)

FIGURE 14: Stress-strain curve of GFRP bars in tension. (a) T-C specimens. (b) T-W specimens.

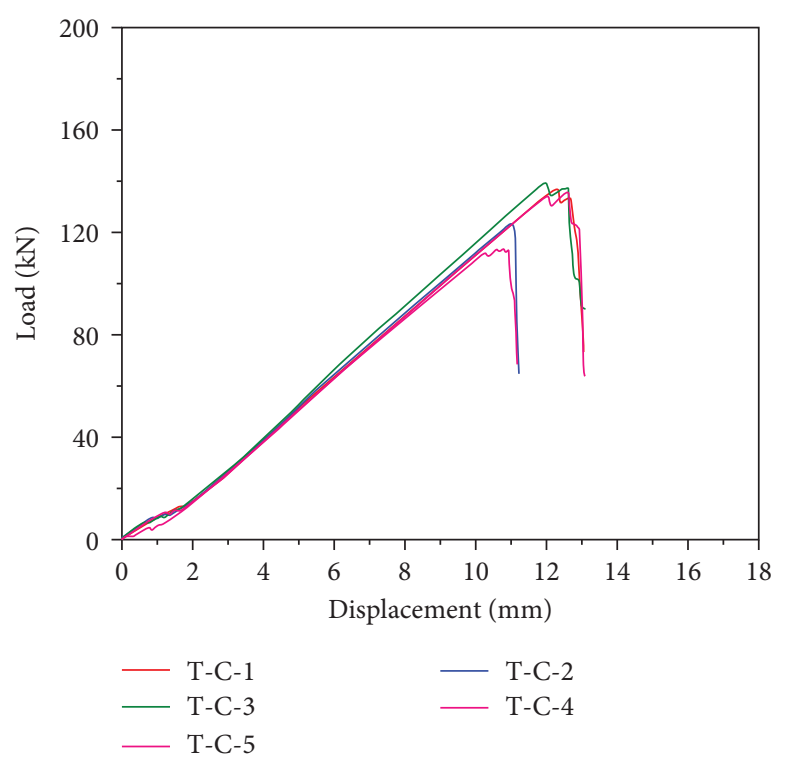

(a)

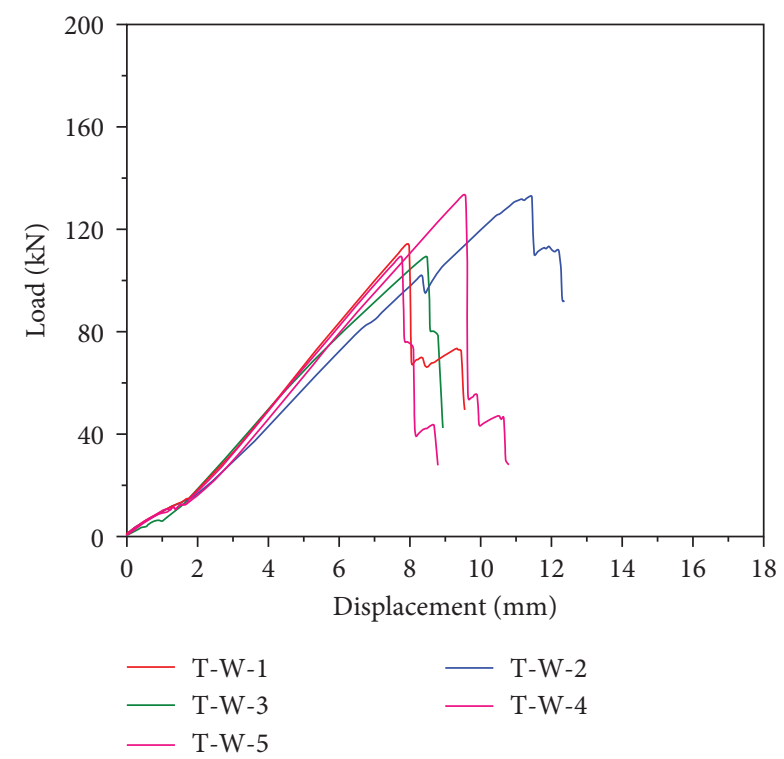

(b)

FIGURE 15: Load-displacement of GFRP bars in tension. (a) T-C specimens. (b) T-W specimens. 


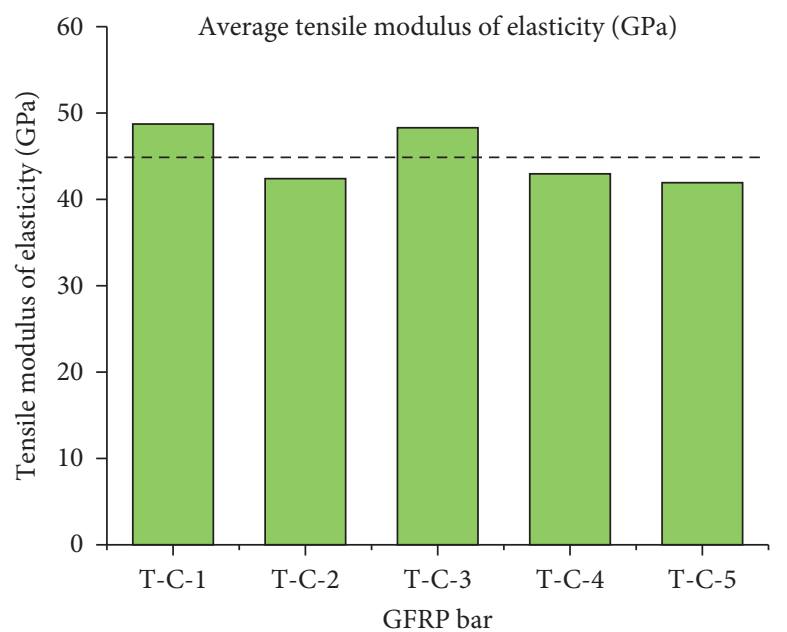

(a)

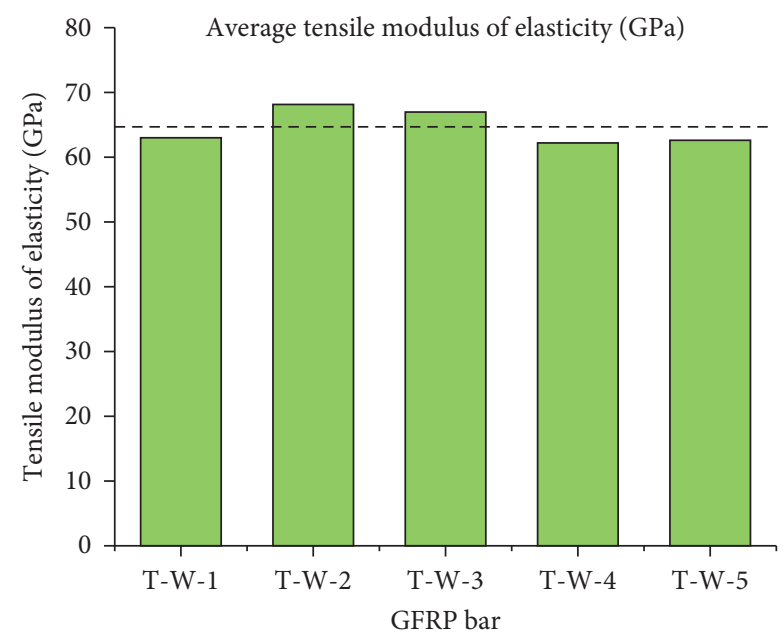

(b)

FIgURE 16: Comparison of tensile modulus of elasticity of (a) T-C specimens and (b) T-W specimens.

TABLe 11: Details of GFRP bars under cyclic loading.

\begin{tabular}{lcccc}
\hline Group notation & Number of winding layers & Diameter $(\mathrm{mm})$ & Length $(\mathrm{mm})$ & Specimen ID \\
\hline TC-C & 0 & 16 & 500 & TC-C-1, TC-C-2, TC-C-3 \\
TC-W & 1 & 21 & 500 & TC-W-1, TC-W-2, TC-W-3 \\
\hline
\end{tabular}

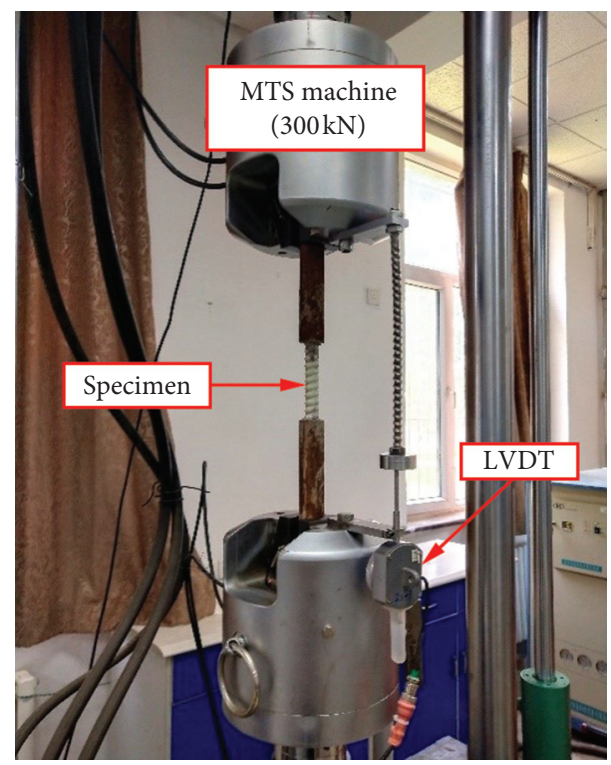

Figure 17: Test setup of GFRP bars under cyclic loading.

Figures 20 and 21 show the hysteresis curves of TC-C specimens and TC-W specimens under cyclic tensioncompression loading test. The red and blue dots indicate the ultimate loads of the GFRP bars during the process of tension or compression loading, respectively.

All the GFRP bars were failed during bearing the compressive load in the cyclic loading test. Compared with TC-C specimens, the compressive failure of TC-W specimens was delayed due to the existence of the winding layer, which played a vital role in the compression stage during the loading process and further improved the compressive ultimate bearing capacity.

Due to the increase of the residual displacement and the ultimate load, the energy dissipation capacity of GFRP bars with winding layers was improved to a certain extent. In addition, the overall stiffness of TC-C specimens was less 


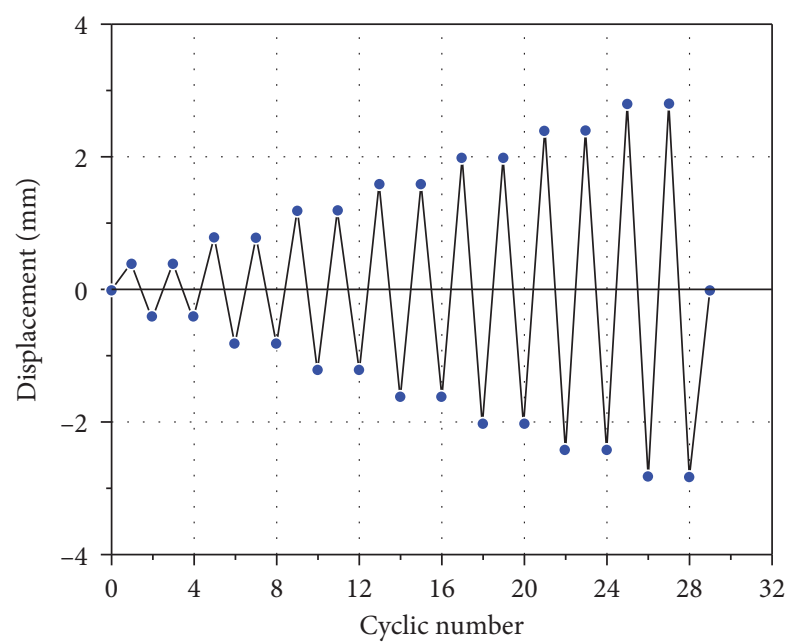

Figure 18: Process of cyclic loading

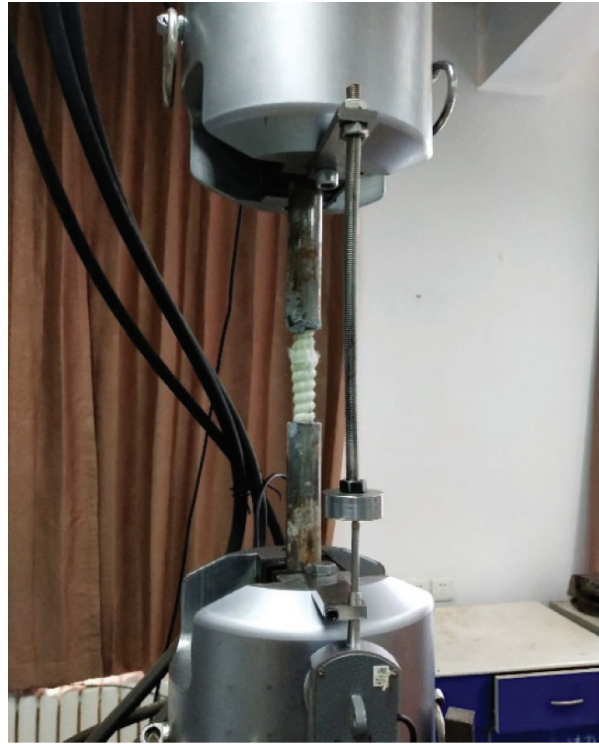

(a)

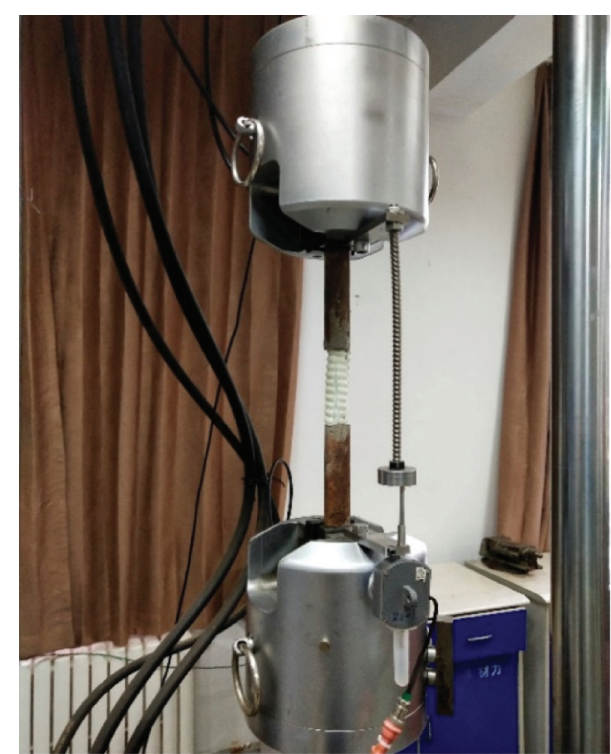

(b)

FIgURE 19: Failure modes of GFRP bars under cyclic loading. (a) TC-C specimen. (b) TC-W specimen.

than that of TC-W specimens, and the energy dissipation capacity of TC-W specimens was better than that of TC-C specimens.

It can be also found from Figures 19 and 20 that the compressive ultimate bearing capacities of GFRP bars were greater than the tensile ultimate bearing capacities, which can explain that the compressive failure of GFRP bars occurred before the tensile failure.
Table 12 presents the comparison between the cyclic loading test and monotonic loading tests. The bearing capacities were the average value of monotonic tensile and compressive tests and cyclic loading test.

Under cyclic loading, the ultimate load of TC-C specimens and TC-W specimens is just approximate $80 \% \sim 90 \%$ of that under monotonic compressive loading and is approximate $45 \% \sim 65 \%$ of that under monotonic tensile loading, 


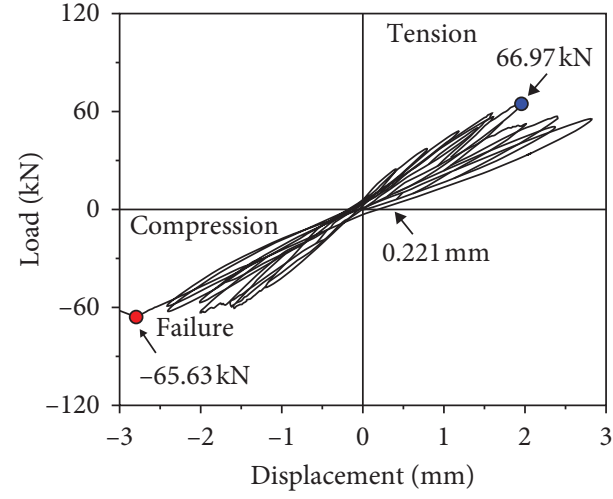

(a)

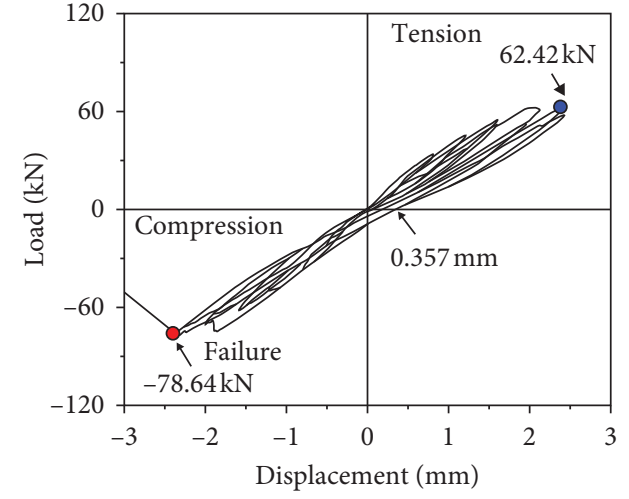

(b)

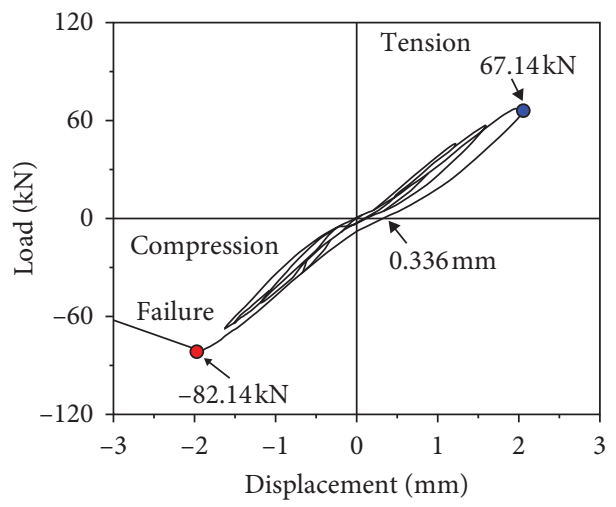

(c)

Figure 20: Hysteretic curve of TC-C specimens. (a) TC-C-1. (b) TC-C-2. (c) TC-C-3.

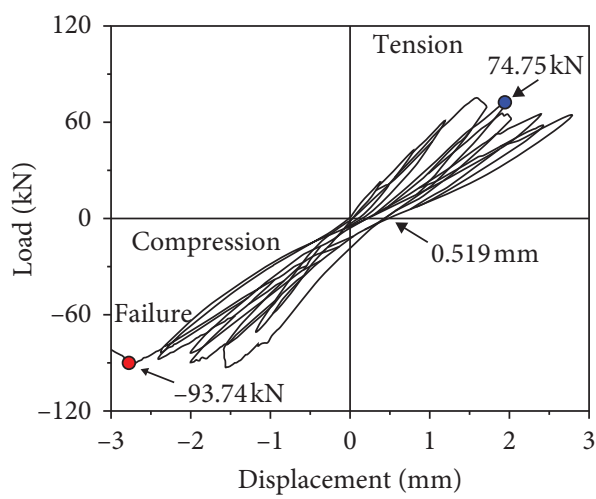

(a)

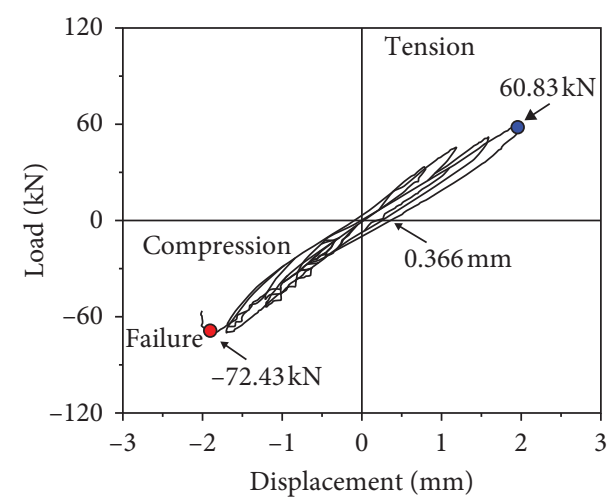

(b)

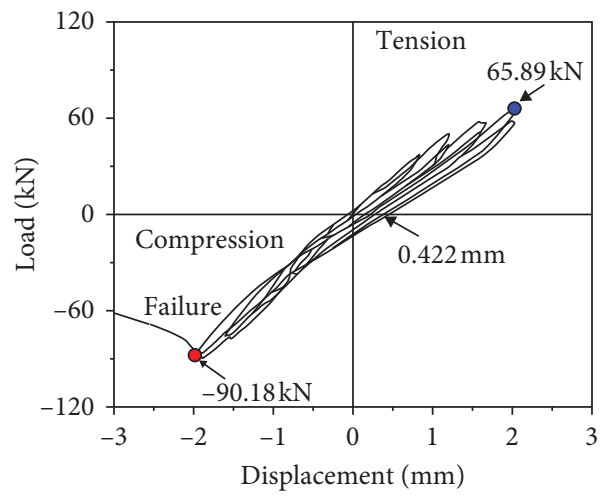

(c)

FIgUre 21: Hysteretic curve of TC-W specimens. (a) TC-W-1. (b) TC-W-2. (c) TC-W-3. 
TABLE 12: Ultimate load comparison between the cyclic loading and monotonic loading.

\begin{tabular}{lccccc}
\hline Load type & Monotonic loading & Bearing capacity $(\mathrm{kN})$ & Cyclic loading & Bearing capacity $(\mathrm{kN})$ & Percentage \\
\hline Compression & C-H40/C-H60 & $92.941 / 84.820$ & TC-C & 75.470 & $81.2 / 89.0$ \\
Tension & T-C & 129.742 & TC-C & 65.510 & 50.5 \\
Compression & W-H40/W-H60 & $103.113 / 101.327$ & TC-W & 85.453 & $82.9 / 84.3$ \\
Tension & T-W & 120.009 & TC-W & 67.157 \\
\hline
\end{tabular}

which indicates that the GFRP bars first reached the compressive ultimate bearing capacities and then failed.

\section{Conclusion}

In this paper, a novel GFRP bar with hoop winding layer is studied through the monotonic compression, monotonic tension, and cyclic tension-compression tests. The mechanical responses were investigated and compared with the tradition GFRP bar. The following key conclusions can be drawn from the work:

(1) The ultimate compressive bearing capacity of the GFRP bars with winding layer is significantly greater than that of the traditional GFRP bars. The stressstrain relationship of the tradition GFRP bar is linear, while that of the novel GFRP bar is nonlinear, and the winding layer can also help improving the compressive ductility of the GFRP bar.

(2) The tensile test results indicate that the stress-strain curves of both GFRP bars are linear, and the winding layer does not greatly influence the tensile strength of the GFRP bar but can slightly increase the tensile elastic modulus.

(3) Under the cyclic tension-compression loading, the compressive ultimate load of the GFRP bar is $80 \%$ $90 \%$ of that under monotonic compressive test, and the tensile ultimate load is $45 \% \sim 65 \%$ of that under monotonic tensile test. Compared with the traditional GFRP bar without winding layer, the deformation of the novel GFRP bar with winding layer is reduced when the same load is applied. Therefore, the overall stiffness of the novel GFRP bar is greater than that of the traditional GFRP bar. Moreover, the ultimate load of the GFRP bar is also increased by the winding layer. In addition, because the residual displacement of the novel GFRP bar is greater than that of the traditional GFRP bar, winding hoop fibers on the outer surface of the core is a useful way to improve the energy dissipation capacity of the GFRP bar.

\section{Data Availability}

The experimental data used to support the findings of this study are available from the corresponding author upon request.

\section{Conflicts of Interest}

The authors declare that there are no conflicts of interest regarding the publication of this paper.

\section{Authors' Contributions}

Yue Liu and Hong-Tao Zhang conceived and designed the analysis. Yue Liu, Hong-Tao Zhang, Hong-Hao Zhao, and Lin Lu performed the analysis and collected the data. Yue Liu, Hong-Tao Zhang, Hong-Hao Zhao, Lin Lu, Ming-Yang Han, Jiao-Cai Wang, and Shuai Guan wrote the paper. Yue Liu, Hong-Tao Zhang, Hong-Hao Zhao, and Lin Lu revised the paper.

\section{Acknowledgments}

The authors would like to acknowledge the funding provided by National Natural Science Foundation (NSFC 51908012), China Postdoctoral Science Foundation (2019M660962), and International Research Cooperation Seed Fund of Beijing University of Technology (2021B11).

\section{References}

[1] F. Cobb, Structural Engineer's Pocket Book, CRC Press, Boca Raton, FL, USA, 2020.

[2] ASCE, 2017 Infrastructure Report Card, ASCE, Reston, VA, USA, 2017.

[3] B. Hou, The Cost of Corrosion in China, Science Press, Beijing, China, 2019.

[4] Y. Liu, T. Tafsirojjaman, A. U. R. Dogar, and A. Hückler, "Shrinkage behavior enhancement of infra-lightweight concrete through FRP grid reinforcement and development of their shrinkage prediction models," Construction and Building Materials, vol. 258, Article ID 119649, 2020.

[5] Y. Liu, T. Tafsirojjaman, A. U. R. Dogar, and A. Hückler, "Bond behaviour improvement between infra-lightweight and high strength concretes using FRP grid reinforcements and development of bond strength prediction models," Construction and Building Materials, vol. 270, Article ID 121426, 2021.

[6] Y. Duo, X. Liu, Y. Liu, T. Tafsirojjaman, and M. Sabbrojjaman, "Environmental impact on the durability of FRP reinforcing bars," Journal of Building Engineering, vol. 43, Article ID 102909, 2021.

[7] L. Yue, Z. Bernd, and S. Mike, "Carbon fiber reinforced polymer for cable structures-a review," Polymers, vol. 7, pp. 2078-2099, 2015.

[8] P. Ai, P. Feng, H. Lin, P. Zhu, and G. Ding, "Novel selfanchored CFRP cable system: concept and anchorage behavior," Composite Structures, vol. 263, Article ID 113736, 2021.

[9] H. Fukuyama, "FRP composites in Japan," Concrete International, vol. 21, no. 10, pp. 29-32, 1999.

[10] S. Rizkalla and P. Labossiere, "Structural engineering with FRP-in Canada," Concrete International, vol. 21, no. 10, pp. 25-28, 1999. 
[11] L. Ye, P. Feng, K. Zhang et al., "FRP in civil engineering in China: research and applications," Fibre-Reinforced Polymer Reinforcement for Concrete Structures, pp. 1401-1412, World Scientific, Singapore, 2003.

[12] A. H. Ali, H. M. Mohamed, and B. Benmokrane, "Bar size effect on long-term durability of sand-coated basalt-FRP composite bars," Composites Part B: Engineering, vol. 195, Article ID 108059, 2020.

[13] Y. Zhou, H. Gao, Z. Hu et al., "Ductile, durable, and reliable alternative to FRP bars for reinforcing seawater sea-sand recycled concrete beams: steel/FRP composite bars," Construction and Building Materials, vol. 269, Article ID 121264, 2021.

[14] B. Benmokrane, A. H. Ali, H. M. Mohamed, A. ElSafty, and A. Manalo, "Laboratory assessment and durability performance of vinyl-ester, polyester, and epoxy glass-FRP bars for concrete structures," Composites Part B: Engineering, vol. 114, pp. 163-174, 2017.

[15] W. Ge, M. Han, Z. Guan et al., "Tension and bonding behaviour of steel-FRP composite bars subjected to the coupling effects of chloride corrosion and load," Construction and Building Materials, vol. 296, Article ID 123641, 2021.

[16] Y. Zhou, H. Fu, P. Li, D. Zhao, L. Sui, and L. Li, "Bond behavior between steel bar and engineered cementitious composite (ECC) considering lateral FRP confinement: test and modeling," Composite Structures, vol. 226, Article ID 111206, 2019.

[17] M. Rezazadeh and V. Carvelli, "A damage model for highcycle fatigue behavior of bond between FRP bar and concrete," International Journal of Fatigue, vol. 111, pp. 101-111, 2018.

[18] S. Solyom and G. L. Balázs, "Bond of FRP bars with different surface characteristics," Construction and Building Materials, vol. 264, Article ID 119839, 2020.

[19] E. Aydın, E. Boru, and F. Aydın, "Effects of FRP bar type and fiber reinforced concrete on the flexural behavior of hybrid beams," Construction and Building Materials, vol. 279, Article ID 122407, 2021.

[20] D. Gao and C. Zhang, "Shear strength prediction model of FRP bar-reinforced concrete beams without stirrups," Mathematical Problems in Engineering, vol. 2020, Article ID 7516502, 11 pages, 2020.

[21] C. Chen, Q. Zeng, Z. Gao, L. Sui, and Y. Zhou, "FRP-reinforced concrete-steel double-skin tubular coupling beam subjected to reversed cyclic loading," Journal of Composites for Construction, vol. 25, no. 4, Article ID 04021033, 2021.

[22] R. El Ghadioui, T. Proske, N. L. Tran, and C.-A. Graubner, "Structural behaviour of CFRP reinforced concrete members under bending and shear loads," Materials and Structures, vol. 53, pp. 1-16, 2020.

[23] H. M. Mohamed, M. Z. Afifi, and B. Benmokrane, "Performance evaluation of concrete columns reinforced longitudinally with FRP bars and confined with FRP hoops and spirals under axial load," Journal of Bridge Engineering, vol. 19, no. 7, Article ID 04014020, 2014.

[24] H. Tobbi, A. S. Farghaly, and B. Benmokrane, "Concrete columns reinforced longitudinally and transversally with glass fiber-reinforced polymer bars," ACI Structural Journal, vol. 109, no. 4, 2012.

[25] G. B. Maranan, A. C. Manalo, B. Benmokrane, W. Karunasena, and P. Mendis, "Behavior of concentrically loaded geopolymer-concrete circular columns reinforced longitudinally and transversely with GFRP bars," Engineering Structures, vol. 117, pp. 422-436, 2016.
[26] N. Elmesalami, F. Abed, and A. E. Refai, "Concrete columns reinforced with GFRP and BFRP bars under concentric and eccentric loads: experimental testing and analytical investigation," Journal of Composites for Construction, vol. 25, no. 2, Article ID 04021003, 2021.

[27] H.-L. Dong, D. Wang, Z. Wang, and Y. Sun, "Axial compressive behavior of square concrete columns reinforced with innovative closed-type winding GFRP stirrups," Composite Structures, vol. 192, pp. 115-125, 2018.

[28] B. Li, P. Zohrevand, and A. Mirmiran, "Cyclic behavior of FRP concrete bridge pier frames," Journal of Bridge Engineering, vol. 18, no. 5, pp. 429-438, 2013.

[29] M. Mady, A. El-Ragaby, and E. El-Salakawy, "Seismic behavior of beam-column joints reinforced with GFRP bars and stirrups," Journal of Composites for Construction, vol. 15, no. 6, pp. 875-886, 2011.

[30] F. Faleschini, J. Gonzalez-Libreros, M. A. Zanini, L. Hofer, L. Sneed, and C. Pellegrino, "Repair of severely-damaged RC exterior beam-column joints with FRP and FRCM composites," Composite Structures, vol. 207, pp. 352-363, 2019.

[31] B. Roy and A. I. Laskar, "Cyclic performance of beam-column subassemblies with construction joint in column retrofitted with GFRP," Structures, vol. 14, pp. 290-300, 2018.

[32] J. P. Firmo, J. R. Correia, and L. A. Bisby, "Fire behaviour of FRP-strengthened reinforced concrete structural elements: a state-of-the-art review," Composites Part B: Engineering, vol. 80, pp. 198-216, 2015.

[33] A. Bilotta, A. Compagnone, L. Esposito, and E. Nigro, "Structural behaviour of FRP reinforced concrete slabs in fire," Engineering Structures, vol. 221, Article ID 111058, 2020.

[34] C. Burgoyne, E. Byars, M. Guadagnini et al., FRP Reinforcement in $R C$ Structures, International Federation for Structural Concrete, Lausanne, Switzerland, 2007.

[35] ACI, Guide for the Design and Construction of Structural Concrete Reinforced with Fiber-Reinforced Polymer Bars, ACI440. 1R-15, vol. 88, American Concrete Institute, Farmington Hills, MI, USA, 2015.

[36] A. Machida and T. Uomoto, Recommendation for Design and Construction of Concrete Structures Using Continuous Fiber Reinforcing Materials, Japan Society of Civil Engineers, Tokyo, Japan, 1997.

[37] T. Siwowski, B. Piątek, P. Siwowska, and A. Wiater, "Development and implementation of CFRP post-tensioning system for bridge strengthening," Engineering Structures, vol. 207, Article ID 110266, 2020.

[38] P. Thiyagarajan, V. Pavalan, and R. Sivagamasundari, "Mechanical characterization of basalt fibre reinforced polymer bars for reinforced concrete structures," International Journal of Applied Engineering Research, vol. 13, pp. 5858-5862, 2018.

[39] Q. S. Khan, M. N. Sheikh, and M. N. Hadi, "Tension and compression testing of fibre reinforced polymer (FRP) bars," in Proceedings of the Joint Conference of 12th International Symposium on Fiber Reinforced Polymers for Reinforced Concrete Structures and the 5th Asia-Pacific Conference on Fiber Reinforced Polymers in Structures, Nanjing, China, 2015.

[40] K. Khorramian and P. Sadeghian, "New testing method of GFRP bars in compression," in Proceedings of the 2018 CSCE Annual Conference 2018, Canadian Society for Civil Engineering, Fredericton, Canada, 2018.

[41] O. S. AlAjarmeh, A. C. Manalo, B. Benmokrane, P. V. Vijay, W. Ferdous, and P. Mendis, "Novel testing and characterization of GFRP bars in compression," Construction and Building Materials, vol. 225, pp. 1112-1126, 2019. 
[42] A. Tavassoli, J. Liu, and S. Sheikh, "Glass fiber-reinforced polymer-reinforced circular columns under simulated seismic loads," ACI Structural Journal, vol. 112, no. 1, p. 103, 2015.

[43] D. H. Deitz, I. E. Harik, and H. Gesund, "Physical properties of glass fiber reinforced polymer rebars in compression," Journal of Composites for Construction, vol. 7, no. 4, pp. 363-366, 2003.

[44] M Urbański, "Compressive strength of modified FRP hybrid bars," Materials (Basel, Switzerland), vol. 13, no. 8, p. 1898, 2020.

[45] A. De Luca, F. Matta, and A. Nanni, "Behavior of full-scale glass fiber-reinforced polymer reinforced concrete columns under axial load," ACI Structural Journal, vol. 107, no. 5, p. 589, 2010.

[46] CSA, Design and Construction of Building Structures with Fibre-Reinforced Polymers, American Concrete Institute, Mississauga, Canada, 2012.

[47] K. Kobayashi and T. Fujisaki, "Compressive behavior of FRP reinforcement in non-prestressed concrete members, nonmetallic (FRP) reinforcement for concrete structures," in Proceedings of the 2nd International RILEM Symposium, p. 267, 1995.

[48] G. Wu, Z.-S. Wu, Y.-B. Luo, Z.-Y. Sun, and X.-Q. Hu, "Mechanical properties of steel-FRP composite bar under uniaxial and cyclic tensile loads," Journal of Materials in Civil Engineering, vol. 22, no. 10, pp. 1056-1066, 2010.

[49] Standardization Administration of the People's Republic of China (SAPRC), Fiber-Reinforced Plastics Composites-Determination of Compressive Properties, GB/T1448-2005, SAPRC, Beijing, China, 2005.

[50] Standardization Administration of the People's Republic of China (SAPRC), Test Method for Basic Mechanical Properties of Fiber-Reinforced Polymer Bar, GB/T 30022-2013, SAPRC, Beijing, China, 2013. 